\title{
RELATIONSHIP BETWEEN JOB CHARACTERISTICS AND ORGANIZATIONAL COMMITMENT WITH JOB SATISFACTION AS MEDIATING VARIABLE: A STUDY AT CONVENTIONAL BANKS IN TERNATE
}

\author{
Jabid Abdullah W.*, Darwis Herman \\ Faculty of Economics and Business, Universitas Khairun Ternate \\ *E-mail: abdullah.jabid@unkhair.ac.id
}

\begin{abstract}
The objective of the study was to develop conceptual method and analyze role of job satisfaction in relationship between job characteristics and organizational commitment in conventional bank in Ternate, North Maluku, Indonesia. The study was an explanatory study that explained causal relationship between variables using quantitative approach. The units of analysis or subjects were back office staffs (clearing, deposit and saving and accounting staffs), front office staffs (teller and customer service) and head of units or branch. The total subjects were 106. The study was conducted between July and December, 2018. The analysis method was Smart Partial Least Square (Smart PLS) version 3.2.7. The findings showed that job characteristics had direct influence on organizational commitment. Job satisfaction was mediating the relationship between job characteristics and organizational commitment. Organizational commitment was partial mediating variable. It means without job satisfaction, job characteristics have influence on organizational commitment.
\end{abstract}

\section{KEY WORDS}

Job, characteristics, job satisfaction, organizational commitment.

Globalization and industrialization creates new fields of study, job and types of organization in financial, banking and telecommunication sector. Human resource plays a vital role in improving performance of an organization. Despite of a sharp increase in fully automated factories, human is still an integral part of an industry. Human is needed for engine operation and maintenance and decision-making.

Commitment is the bond employees experience with their organization. Committed employees help organization achieve its target. Therefore, organization should pay attention to its employees since employees with high job satisfaction will have high commitment. Organization should create good working atmosphere, provide sufficient facilities and selfdevelopment programs for its employees.

Organizational commitment is a multidimensional construct that explains relationship between individuals and their organizations (Glazer et al., 2004). Organizational commitment is associated to job characteristics. Some experts argue that there is a positive correlation between all dimensions of job characteristics (skill variation, task identity, task significance, autonomy, and feedback) and organizational commitment (Abu Elanain, 2009). However, other researchers revealed that only a few dimensions of job characteristics that influence organizational commitment. For example, Bhuian et al. (1996) showed that out of the five dimensions of work variation, job variation is the only one having a significant influence on organizational commitmen. Furthermore, other studies revealed that job characteristics have positive and significant correlation with affective commitment, while job characteristics do not have any significant correlation with either continuous and normative commitment (Madi et al., 2012).

Workers in banking sectors spend most of their time at work and therefore, job characteristics and work environment have significant influence on organizational commitment. Watson Wyatt's (2005) study, involving 515 companies, and 115,000 workers in Indonesia and Asia, found dualism among Indonesian workers. $85 \%$ of the workers were proud of their job (the percentage is higher than that of Asia Pacific workers of $77 \%$ ), $80 \%$ of the staffs were confident that their companies can achieve their long-term goals (the 
percentage is also higher than that of Asia Pacific workers of only), but only $35 \%$ of Indonesian workers want to keep working in their companies even though when they leave their current work and start working in other companies, they will be given the same amount of salary, workload and responsibility. Wyatt's study noted that commitment index of Indonesian workers is $57 \%, 7$ points lower than that of Asia Pacific workers. Indonesia has one of the lowest commitment indexes in Asia Pacific (www.portalhr.com).

Another study shows that many companies in Indonesia, including companies in banking sector, pay very little attention to commitment index of their workers. Towers Watson conducted Talent Management and Reward Survey (2012) taking 52 companies as samples, one-third of which are banks, and found out that companies did not pay attention to factors that influence worker's decision to keep or leave their current jobs (www.infobanknews.com).

Banking sector in Ternate is competitive. There are 10 reputable conventional banks, namely BRI, BNI, Bank Mandiri, Bank BTPN, Bank Megah, BCA, BTN, Bank Nobu, BII, and Bank Bobato and 4 sharia banks, Bank Muamalat, Bank BNI Syariah, Bank Mandiri Syariah and BPRS Bahari Berkesan in the city (KBI Kota Ternate, 2018).

To prevent its staffs from moving to other companies, each bank should conduct programs that aim to increase job satisfaction and commitment of its staffs. Bank staffs should ocassionally work overtime and spend less time with their family despite getting overtime pay.

Job characteristic is affective factors that influence employees' intrinsic motivation (Hackman and Oldham, 1976). Job characteristics model has been recorded as one of the best job enrichment methods which leads to job satisfaction (Yen et al, 2007). Job characteristics models suggests that the five main dimensions of job characteristics result in psychological entity that influences personal characteristics of an employee and his or her work outcome such as motivation, satisfaction, and outgoing desire (Hackman and Oldham, 1975), and psychological empowerment that leads to job satisfaction (Liden et al. 2000). Employees with such psychological state tend to have higher levels of work motivation and work more effectively and under the right circumstances, employees have stronger motivation and higher job satisfaction when a job has a higher level of characteristics (McShane and Von Glinow, 2013).

Organization is more productive when employees are passionate about their work (Spector, 2000). Some previous studies stated that job characteristics (job variation, job identity, job significance, autonomy and feedback) have positive influence towards job satisfaction (Abdul Hamid, 2017; Al-Tit dan Suifan, 2015, dan; Andrew et al., 2016).

However, othe researchers noted that only a few of Hackman dan Oldham's job characteristic dimensions (1975) have positive influence on job satisfaction. Janjhua et al., (2016) argued that autonomy does not influence job satisfaction; Bhuain et al., (1996) explained that the dimensions does not have influence on job satisfaction and Ozturk et al., (2014) found out that neither job variation or job identity influenced job satisfaction.

Job satisfaction is associated to organizational commitment. Researchers, in general, concluded that satisfaction has positive and significant influence towards organizational commitment (Bhuian et al., 1996; Masood et al., 2013; Madi et al., 2012). Nevertheless, other researchers, for example Sharma et al., (2012) who claimed that salary and flexibility have positive and significant influence towards organizational commitment, but neither promotion or supervisors has significant influence towards organizational commitment.

Based on Price Waterhouse Coopers (PWC) survey in 2012, 54\% respondents were thinking of leaving their job to get better compensation, 37\% respondents were thinking of leaving their job because their current job does not have clear career path, $4 \%$ respondents wanted to find a more challenging job and the remaining $4 \%$ were not satisfied with leadership style their supervisors applied (www.financial.bisnis.com).

In banking sectors, employees are responsible for product introduction and providing service. Therefore, low job satisfaction can result in poor service and company fail to achieve its target. Therefore, it is pivotal for banking sector to measure job satisfaction and commitment of employees since job satisfaction influences quality of service employees can provide. 
To bridge the research gap, this recent study involves a new variable, job satisfaction in relationship between job characteristic and organizational commitment. All dimensions of job characteristics have positive but partial influence on organizational commitment (Abu Elanain, 2009). At the opposite, Bhuian, et.al (1996) argued that job variation is the only dimension that influences organizational commitment.

Several studies also confirmed relationship between characteristics and job satisfaction, for example Abdul Hamid (2017); Al-Tit dan Suifan, (2015), and Andrew et al., (2016). All of these studies provided empirical evidence that job characteristics (job variation, job identity, job significance, autonomy and feedback) have positive influence on job satisfaction.

However, several studies noted that job variation does not have influence on job satisfaction (Bhuian et al., 1996); job variation and job identity do not have significant influence on job satisfaction (Ozturk, 2014); feedback has negative and significant influence on job satisfaction (Hadi and Adil, 2010).

Inconsistent findings of the previous studies encourage the researchers to develop conceptual model and investigate role of job satisfaction in relationship between job characteristics and organizational commitment in 10 conventional banks in Ternate, particularly role of job satisfaction as mediating variable. To bridge the research gap, this study reconstructs a model involving three variables, job characteristics, job satisfaction and organizational commitment.

\section{LITERATURE REVIEW}

Job characteristic is affective factors that influence employees' intrinsic motivation (Hackman and Oldham, 1976) (Hackman dan Oldham, 1976). McShane dan Von Glinow (2013) stated that employees with high level of job satisfaction are highly motivated and thus, work more effectively. Under certain circumstances, employees are motivated and satisfied with their job when they have higher job characteristics (McShane dan Von Glinow, 2013).

Several previous studies show that job characteristics (job variation, job identity, job significance, autonomy and feedback) have positive influence on job satisfaction (Abdul Hamid 2017; Al-Tit dan Suifan 2015, dan; Andrew et al., 2016), and Janjhua et al., (2016) found out that there is positive relationship between four aspects of job characteristics (significance, job identity, job variation and feedback) and job satisfaction. As an addition, Bhuian et al., (1996) argued that there is a positive relationship between job satisfaction and autonomy, job identity and feedback. Job variation did not have influence towards job satisfaction.

Ozturk (2014) stated that out of the five dimensions of job characteristics, autonomy, feedback and interaction have significant influence on job satisfaction whereas job variation and identity do not. On the other hand, Hadi and Adil (2010) reported that job variation, significance and job identity have positive and significant influence towards job satisfaction while feedback has negative and significant influence towards job satisfaction.

Hypothesis 1: Job characteristics have positive influence towards job satisfaction.

Nwosu et al's study (2013) revealed that out of seven dimensions of job characteristics, two dimensions (relationship with other people and job identity) can predict organizational commitment while the other five (job variation, significance, autonomy, feedback from work and feedback from agent) cannot. Thirunavukarasu and Sritharan (2016) stated that job variation, feedback and relationship with other people can predict organizational commitment but autonomy and job identity cannot.

Abu Elanain's study (2009) proved positive relationship between all dimensions of job characteristics (job variation, job identity, significance, autonomy and feedback) and organizational commitment. At the opposite, Bhuian et al., (1996) showed that autonomy, job identity and feedback did not have influence towards organizational commitment.

Investigating rekationship between job characteristic and organizational commitment, Madi et al., (2012) stated that job characteristic has positive and significant relationship with affective commitment, but it does not have relationship with continuous or normative 
commitment. However, in general, the study showed that job characteristic has positive and significant relationship with commitment. As an adition, Ozturk et al., (2014), investigating relationship between job characteristic and affective commitment, noted that autonomy, feedback and interaction have significant influence on affective commitment but job variation and job identity do not.

Hypothesis 2: Job characteristics have positive influence on organizational commitment.

Daileyl and Kirk (1992) stated that job satisfaction is an indicator of organizational commitment. Committed workers have high job satisfaction and thus, poorly-commited individuals have low job satisfaction. Silva (2006) and Eliyana et al., (2012) noted that job satisfaction has significant influence on organizational commitment.

Factors that contribute to job satisfaction, such as, satisfaction on work environment, job itself, reward (employment status, job security, benefit and salary) have positive influence on job satisfaction. Reward is the most important factor to predict manager's job satisfaction in general. The second and third most important factors are work environment and job itself. On the other hand, job security, as a part of reward, is the most important factor for workers. Work environment and job are two significant factors to predict job satisfaction in general (Lam et al., 2001).

Some studies confirm that job satisfaction has positive influence on organizational commitment, for example Daileyl and Kirk (1992), Lambert and Hogan (2009), Kanwar et al., (2012), and Mosadeghrad et al., (2008). As an addition, lqbal et al., 2014, Mohamed et al., 2014; Yousef, 2001, Hayati and Chaniago, 2012, Marri et al., 2012, and Elangovan 2001 showed that job satisfaction has positive and significant influence on organizational commitment.

Ding and Lin (2006) investigated relationship between job satisfaction and organizational commitment among Taiwanese and American workers. The study shows that job satisfaction have more significant influence on organizational commitment in Taiwanese workers compared to American workers.

Freund (2005) conducted a study investigating relationship between job satisfaction and affective commitment. As an addition, Moynihan et al (2000), Clugston (2000), Yousef (2002), Yang (2010), and Malik Farooq, et al (2010) showed that job satisfaction has positive and significant influence on affective commitment. Yang (2010) and Clugston (2000) stated that job satisfaction has positive and significant influence on continuous commitment. Furthermore, Clugston (2000) and Yousef (2002) noted that job satisfaction gas positive influence towards normative commitment. On the other hand, Yousef (2002) concluded that job satisfaction has negative influence towards continuous commitment (low alternative/high personal satisfaction).

Hypothesis 3: Job satisfaction has positive influence on organizational commitment.

Crede, et.al (2007) investigating role of job satisfaction in relationship between job characteristics (job variation, job identify, significance, autonomy and feedback) and job withdrawal, organizational citizenship and contraproductive behavior at work. The findings showed that job satisfaction was mediating relationship between job characteristics and all of the dependent variables (job withdrawal, organizational citizenship and contraproductive behavior at work).

As an addition, Awais, et.al (2010) analyzed role of job satisfaction as mediating variable in relationship between spiritual intelligence and organizational commitment. The study revealed that job satisfaction was mediating relationship between spiritual intelligence and organizational commitment. Sharma and Azmi (2012), conducting a study on how much influence job satisfaction has on organizational commitment, explained that job satisfaction was mediating relationship between organizational commitment and satisfaction on salary, promotion, supervision and flexible work schedule.

Carmeli and Freund (2004), investigating role of job satisfaction as mediating variable in relationship between organizational commitment (affective, continuous and career commitment) and productivity, noted that job satisfaction was mediating relationship between organizational commitment (affective, continuous and career commitment) and productivity. 
Sušanj and Jakopec (2012) conducted a study on role of job satisfaction in relationship between organizational commitment and organizational justice. They stated that job satisfaction was mediating relationship between organizational commitment and organizational justice.

Furthermore, Mai, et.al (2016) analyzed role of job satisfaction as mediating variable in relationship between job performance and career development, teamwork, relationship between co-workers, salary and benefit and work environment. Toban and Sjahruddin (2016) investigated role of job satisfaction in relationship between transformational leadership and service quality. Furthermore, I Gede Riana (2015) explained role of job satisfaction as mediating variable in relationship between motivation and business performance. Grobelna, et.al (2016) stated that job satisfaction was mediating relationship between support from management and intrinsic motivation as resource and relationship between affective commitment and role conflict and conflict of ambiguity.

Hypothesis 4: Job satisfaction is mediating relationship between job characteristic and organizational commitment.

\section{METHODS OF RESEARCH}

Objective of this study was to explain relationship and causal relationship between variables in order to develop a model that explained relationship between the variables (job characteristic, job satisfaction and organizational commitment). Thus, this study can be categorized as explanatory research or causality research which consisted of the following steps, namely 1) identify research problem or topic, 2) conduct review of related literature, 3) develop theoretical framework and hypothesis, and 4) hypothesis testing for verification (Solimun, 2012). This study used positivism or quantitative approach.

The data analysis method was inductive statistics, namely descriptive and inferential. The instrument used for data analysis was Structural Equation Modelling (SEM) with Variance Based SEM approach known as Partial Least Square or PLS (Smart PLS Version 3.2.7) designed for variance-based structural equation estimation.

\section{RESULTS AND DISCUSSION}

Based on the analysis, job satisfaction was mediating relationship between job characteristics and organizational commitment. Path coefficient showing relationship between job characteristics and organizational commitment fell sharply to 0.358 since job satisfaction has significant contribution to organizational commitment.

Table 1 - Path Coefficient Analysis Result on Inner Model

\begin{tabular}{llllll}
\hline Relationship & $\begin{array}{l}\text { Path } \\
\text { Coefficient }\end{array}$ & $\begin{array}{l}\text { Standard } \\
\text { Deviation }\end{array}$ & t & P & Result \\
\hline Direct Influence & 0.575 & 0.066 & 8.699 & 0.000 & $\begin{array}{l}\text { Significant } \\
\text { Job characteristics --> Job satisfaction }\end{array}$ \\
Job characteristics --> Organizational commitment & 0.358 & 0.110 & 3.256 & 0.001 & Significant \\
Job satisfaction --> Organizational commitment & 0.423 & 0.122 & 3.463 & 0.001 & Significant \\
Indirect Influence & & & & & \\
Job characteristics --> Organizational commitment & 0.243 & 0.087 & 2.793 & 0.005 & Significant \\
\hline
\end{tabular}

Source: Primary Data (2018).

Smart PLS 3.2.7 was used on the developed model in order to find out significance of the path coefficient and for hypothesis-testing (Hartono and Abdillah, 2009; Ghozali, 2008). Path coefficient was significant when $p$ was lower than 0.05 Figure 1 and Table 1 summarized result of inner model. The following section is the researchers' interpretation on relationship between the variables.

Coefficient showing relationship between job characteristic and job satisfaction was positive. Based on Table 1, the path coefficient was 0.575 and t-statistics was $8.699(p<0.05)$ 
which means job characteristics have significant influence on job satisfaction. Therefore, $\mathrm{H}_{1}$ was accepted.

Coefficient showing relationship between job characteristics and organizational commitment was positive. Table 1 showed that the path coefficient was 0.358 and t-statistics was $3.256 \quad(p<0.05)$ which means job characteristics have significant influence on organizational commitment. Job characteristics can explain level of organizational commitment directly. Based on the analysis, $\mathrm{H}_{2}$ was accepted.

Coefficient showing relationship between job satisfaction and organizational commitment was positive. Table 1 showed that the path coefficient was 0.423 and t-statistics sebesar $3.463 \quad(p<0.05)$ which means job satisfaction has significant influence on organizational commitment. High job satisfaction increased organizational commitment. Therefore, $\mathrm{H}_{3}$ was accepted.

Coefficient showing role of job satisfaction as mediating variable in relationship between job characteristics and organizational commitment was positive $(0.575 \times 0.423=$ $0.243)$. Based on Table 1, the coefficient was 0.243 and t-statistics was $2.793(p<0.05)$ which means that job satisfaction was mediating relationship between job characteristics and organizational commitment. As an addition, coefficient showing relationship between job characteristics and organizational was 0.601 (total sum of both direct and indirect influence). The analysis confirmed that $\mathrm{H}_{4}$ was accepted.

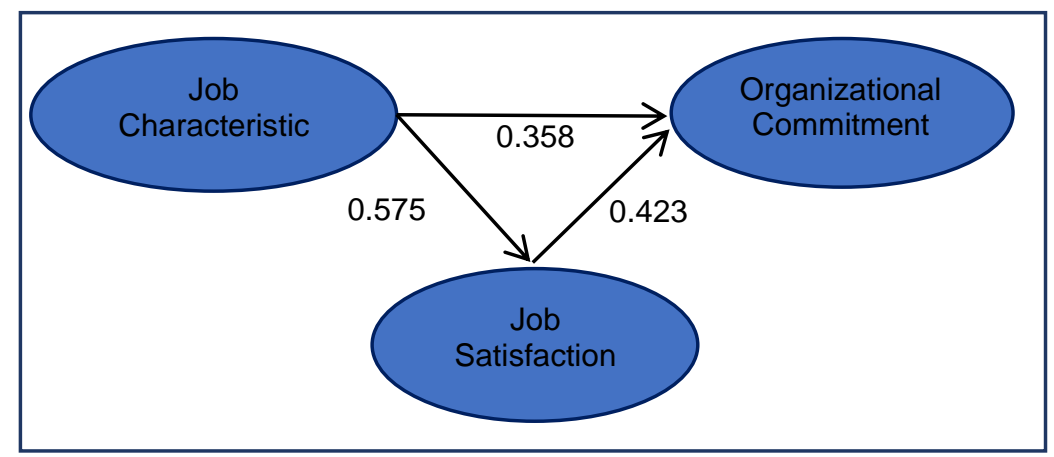

Figure 1 - Job Satisfaction as Mediating Variable in Relationship between Job Characteristics and Organizational Commitment (Source: Primary Data, 2018)

\section{DISCUSSION OF RESULTS}

First; the analysis showed that job characteristics had positive and significant influence on job satisfaction. It shows that the first hypothesis can be accepted. The finding provides empirical evidence that good job characteristics in the conventional banks in Ternate will improve job satisfaction of the bank employees.

The finding is in line with Abdul Hamid (2017); Al-Tit and Suifan (2015), and; Andrew et al., (2016) that there is positive relationship between job characteristics (job variation, job identity, significance, autonomy and feedback) and job satisfaction. However, the finding of the study does not support findings of several previous related studies, for example Janjhua, et.al (2016) who stated that autonomy did not have significant influence on job satisfaction, Bhuian, et.al's study (1996) who argued that job variation did not have influence on job satisfaction on job satisfaction, Ozturk (2014) who reported that job variation and job identity did not have significant influence on job satisfaction and Hadi and Adil (2010) who revealed that feedback has negative and significant influence towards job satisfaction.

Job characteristics refers to nature of a job perceived and experienced by an employee; this affects psychological condition of the employee (Linz, 2003). Employee who experience this psychological state tends to have higher motivation and work more effectively. Under the right situation, employees have higher motivation and job satisfaction when they are assigned a job with higher characteristics (McShane and Von Glinow, 2013).

Secondly; job characteristics, in this study, refer to job variation, job identity, significance, autonomy and feedback. Organizational commitment will increase when job 
characteristics, which influence psychological condition of employees, is improving. Organizational commitment can be measured based on three dimensions, namely affective, continuous and normative commitment. Out of the three, affective commitment, employee's positive emotional attachment to his or her organization, has the highest loading factor. Several factors that affect affective commitment are good work environment, security and benefits employees gain from working at the conventional banks. When bank employees are given good working environment and feel secured, they are committed to their work. On the other hand, continuous commitment has the lowest loading factor.

The finding of the study showed that job characteristics have positive and significant influence on organizational commitment. Committed employees are ones who have high job characteristics. The finding is in accordance to Abu Elanain (2009) that there is positive relationship between all dimensions of job characteristics (job variation, job identity, significance, autonomy, and feedback) and organizational commitment. The finding also supports Bhuian, et.al (1996) that job variation has significant influence on organizational commitment. However, the finding is at the opposite of Bhuian, et.al (1996) that some elements of job characteristics, namely autonomy, job identity and feedback, do not have influence on organizational commitment.

Third; employees have high job satisfaction when they are satisfied with their job variation and feedback they get from their supervisors and also when they have good relationship with their co-workers. Satisfied employees are committed to their work/ organizations. Therefore, effort the conventional banks can make to improve organizational commitment of their employees is to improve their normative and continuous commitment and maintain their affective commitment.

The finding is in accordance to Daileyl and Kirk (1992); Lambert and Hogan (2009); Kanwar et al., (2012); Mosadeghrad et al., (2008); lqbal et al., (2014); Mohamed et al., (2014); Yousef (2001); Hayati and Chaniago (2012), Marri et al., (2012), and Elangovan (2001) that job satisfaction has positive and significant influence on organizational commitment.

Fourth; this study also revealed that job satisfaction was mediating relationship between job characteristics and organizational commitment. This finding supports findings of some previous related studies, for example Awais, et.al (2010) that job satisfaction was mediating relationship between spiritual intelligence and organizational commitment, Sharma and Azmi (2012) that job satisfactin was mediating relationship between organizational commitment and satisfaction on salary, promotion, supervision and flexible work schedule, Carmeli and Freund (2004) that job satisfaction was mediating relationship between productivity and all dimensions of organizational commitment (affective, continuous and career commitment, Crede, et.al (2007) that job satisfaction was mediating relationship between job characteristics and job withdrawal, organizational citizenship and contraproductive behavior at work and Sušanj and Jakopec (2012) that job satisfaction was mediating relationship between justice and organizational commitment.

The study has several limitations, namely:

- The study is limited to analyzing several variables that influence organizational commitment while organizational commitment is influenced by OCB (Organizational Citizenship Behavior), organizational culture and individual characteristics;

- The study uses only one dependent variable, organizational commitment, and the study did not investigate relationship between organizational commitment and performance of an organization or job performance;

- The study did not investigate response of the conventional bank's managers or its staffs either;

- The study is limited to conventional bank and therefore, the findings cannot be generalized. 


\section{REFERENCES}

1. Abu, E. H. M. (2009). Job Characteristics, Work Attitudes and Behaviors in Non-Western Context. Journal of Management Development, 28(5), 457-477.

2. Abdul, H. A. K. (2017). Effects of Job Characteristics on Employee Satisfaction in the Public Radio Stations in Syria. International Journal of Academic Research in Business and Social Sciences, 7(9), 294-304.

3. Al-Tit, A. A., and Suifan, S. T. (2015). The Mediating Role of Job Characteristics in the Relationship between Organizational Commitment and Job Satisfaction. International Journal of Business and Management, 10(9), 215 - 222.

4. Andrew, L., Haris, N., Zakaria, H., and Nur, A. Bt. Z. (2016). Job Characteristics and Job Satisfaction among Employees: A Case Study at Craun Research Sdn. Bhd., Kuching, Sarawak. International Academic Research Journal of Business and Technology, 2(2), 165-171.

5. Awais, M., Maik, M. S. M., and Qaisar, A. (2010). A Review: The Job Satisfaction Act as Mediator between Spiritual Intelligence and Organizational Commitment. International Review of Management and Marketing, 5(4), 203-210.

6. Bhuian, N. S., Al-Shammari, S. E., and Jefri, A. O. (1996). Organizational Commitment, Job Satisfaction and Job Characteristics: An Empirical Study of Expatriates in Saudi Arabia. International Journal of Commerce and Management, 6, (3/4), 57-80.

7. Carmeli, A., and Freund, A. (2004). Work Commitment, Job Satisfaction, and Job Performance: An Empirical Investigation. International Journal of Organization Theory and Behavior, 6(4), 289-309.

8. Clugston, M. (2000). The Mediating Effects of Multidimensional Commitment on Job Satisfaction and Intent to Leave. Journal of Organizational Behavior, 21, 477-486.

9. Crede, M., Chernyshenko, O. S., Stark, S., Dalal, R. S., and Bashshur, M. (2007). Job Satisfaction as Mediator: An Assessment of Job Satisfaction's Position Within the Nomological Network. Journal of Occupational and Organizational Psychology, 80(3), 515-538.

10. Daileyl, C., Robert., and Kirk, J. D. (1992). Distributive and Procedural Justice as Antecedents of Job Dissatisfaction and Intent to Turnover. Human Relations, 45(3), 305317.

11. Elangovan, A. R. (2001). Causal Ordering of Stress, Satisfaction and Commitment, and Intention to Quit: A Structural Equations Analysis. Leadership dan Organization Development Journal, 22(4), 159-165.

12. Eliyana, A., Yusuf, R. M., and Prabowo, K. (2012). The Influence of Employee's Job Satisfaction Factors on Organizational Commitment. American Journal of Economics, Special Issue, 141-144.

13. Ghozali, I. (2008). Structural Equation Modelling ( $\left.{ }^{\text {nd }} \mathrm{Ed}\right)$. Semarang: Universitas Diponegoro.

14. Glazer, S., Daniel, S. C., and Short, K. M. (2004). A Study of the Relationship between Organizational Commitment and Human Values in Four Countries. Human Relations, 57(3), 323-345.

15. Grobelna, A., Sidorkiewicz, M., and Kocik, A. T. (2016). Job Satisfaction Among Hotel Employees: Analyzing Selected Antecedents and Job Outcomes. A Case Study from Poland. Argumenta Oeconomica, 2(37), 281-310.

16. Hackman, J. R., and Oldham, G. R. (1976). Motivation Through the Design of Work: Test of a Theory. Organizational Behavior and Human Performance, 16, 250-279.

17. Hackman, J. R., and Oldham, G. R. (1975). The Job Diagnostic Survey: An Instrument for the Diagnosis of Jobs and the Evaluation of Job Redesign Projects. New Haven: Yale University.

18. Hadi, R., and Adil, A. (2010). Job Characteristics as Predictors of Work Motivation and Job Satisfaction of Bank Employees. Journal of the Indian Academy of Applied Psychology, 36(2), 294-299. 
19. Hartono, J., and Abdillah, W. (2009). Konsep dan aplikasi PLS (Partial Least Square) untuk penelitian bisnis. Yogyakarta: BPFE.

20. Hayati, K., Caniago, I. (2012). Islamic Work Ethic: The Role of Intrinsic Motivation, Job Satisfaction, Organizational Commitment and Job Performance. Procedia-Social and Behavioral Sciences, 65, 1102-1106.

21. I Gede, R. (2015). Effects Motivation on Business Performance: The Mediation Role of Job Satisfaction and Leadership (A Study in Village Credit Institutions). European Journal of Business, Economics and Accountancy, 3(2), 1-11.

22. Iqbal, S., Ehsan, S., Rizwan, M., and Noreen, M. (2014). The Impact of Organizational Commitment, Job Satisfaction, Job Stress and Leadership Support on Turnover Intention in Educational Institutes. International Journal of Human Resource Studies, 4(2), 181195.

23. Kanwar, Y. P. S., Singh, A. K., and Amitabh, D. (2012). A Study of Job Satisfaction, Organizational Commitment and Turnover Intent among the IT and ITES Sector Employees. Vision, 16(1), 27-35.

24. Lambert, E., and Hogan, N. (2009). The Importance of Job Satisfaction and Organizational Commitment in Shaping Turnover Intent: A Test of a Causal Model. Criminal Justice Review, 34(1), $96-118$.

25. Liden, R. C., Wayne, S. J., and Sparrowe, R. T. (2000). An Examination of The Mediating Role of Psychological Empowerment on the Relations Between the Job, Interpersonal Relationships, and Work Outcomes. Journal of Applied Psychology, 85, 407-416.

26. Linz, S. J. (2003). Job satisfaction among Russian Workers. Journal of Manpower, 24(6), 626-652.

27. Madi, M., Abu, J. I., and Alqahtani, A. H. M. (2012). Employees' Perception and Organizational Commitment: A Study on the Banking Sector in Gaza, Palestine. International Journal of Business and Social Science, 3(16), 299-312.

28. Malik, F. O., Waheed, A., and Malik, K. U. R. (2010). The Mediating Effects of Job Satisfaction on Role Stressors and Affective Commitment. International Journal of Business and Management, 5(11), 223-235.

29. Marri, K. M. Y., Sadozai, A. M., Zaman, F. H. M., and Ramay, I. M. (2012). The Impact of Islamic Work Ethics on Job Satisfaction and Organizational Commitment: A Study of Agriculture Sector of Pakistan. International Journal of Business and Behavioral Sciences, 2(12), 32-45.

30. Masood, U. H., Rabia, K., and Kashif, N. (2013). The Effects of Personal Characteristics on Organizational Commitment Through Job Satisfaction: An Empirical Study of Pakistan's Financial Sector. Middle-East Journal of Scientific Research, 16(7), 942-951.

31. McShane, S. L., and Von, G. M. A. (2013). Organizational Behavior. Singapore: McGrawHill.

32. Mohamed, N., Abdul, K. N. S., and Hussein, R. (2014). Linking Islamic Work Ethic to Computer Use Ethics, Job Satisfaction and Organisational Commitment in Malaysia. Journal of Business Systems, Governance and Ethics, 5(1), 13-23.

33. Moynihan, M. L., Boswell, R. W., and Boudreau, W. J. (2000). The Influence of Job Satisfaction and Organizational Commitment on Executive Withdrawal and Performance. Center for Advanced Human Resource Studies (CAHRS). Working Paper \#00-16). Ithaca, NY: Cornell University.

34. Mosadeghrad, A. M., Ferlie, E., and Rosenberg, D. (2008). A Study of The Relationship between Job Satisfaction, Organizational Commitment and Turnover Intention among Hospital Employees. Health Services Management Research, 21, 211-227.

35. Nwosu, H. O., Chiamaka, J. A. O., and Tochukwu. O. M. (2013). Job Characteristics as Predictors of Organizational Commitment among Private Sector Workers in Anambra State, Nigeria. International Journal of Asian Social Science, 3(2), 482-491.

36. Ozturk, A. B., Hancer, M., and Im Jin, Y. (2014). Job Characteristics, Job Satisfaction, and Organizational Commitment for Hotel Workers in Turkey. Journal of Hospitality Marketing \& Management, 23(3), 294-313.

37. Sharma, G. M., and Azmi, F. T. (2012). Job Satisfaction as a Mediator in the Relationship 
between Job Factors and Organizational Commitment: A Study of B-School Teachers. IMS Manthan, 7(2), 75-86.

38. Silva, P. (2006). Effects of Disposition on Hospitality Employee Job Satisfaction and Commitment. International Journal of Contemporary Hospitality Management, 18(4), 317328.

39. Solimun. (2012). Penguatan Confirmatory Research: Permodelan Persamaan Struktural, Aplikasi Software GSCA. Malang: FMIPA Universitas Brawijaya.

40. Sušanj, Z., Jakopec, A. (2012). Fairness Perceptions and Job Satisfaction as Mediators of the Relationship between Leadership Style and Organizational Commitment. Psychological Topics, 21(3), 509-526.

41. Spector, P. E. (2000). Industrial and Organizational Psychology ( $2^{\text {nd }}$ Ed). New York: John Wiley \& Sons.

42. Thirunavukarasu, S., and Sritharan, R. (2016). A Study of Relationship between Job Characteristics and Organisational Commitment among Private Sectors, Cuddalore. International Journal of Engineering and Management Research, 6(5), 369-371.

43. Toban, C., and Sjahruddin, H. (2016). The Antecedent and Consequence of Organizational Commitment and Job Satisfaction. Journal of Business and Management Sciences, 4(2), 26-33.

44. Tower, W. (2012). Talent Management and Reward Survey. Retrieved from www.infobanknews.com.

45. Watson, W. (2005). Membedah Pandangan Karyawan Indonesia. Retrieved from www.portalhr.com.

46. Yang, J. T. (2010). Antecedents and Consequences of Job Satisfaction in the Hotel Industry. International Journal of Hospitality Management, 29, 609-619.

47. Yen-Ju, L. B., Yeh, C.Y., and Lin, H. W. (2007). The Influence of Job Characteristics on Job Outcomes of Pharmacists in Hospital, Clinic, and Community Pharmacies. Journal of Medical System, 31, 224-229.

48. Yousef, A. D. (2001). Islamic Work Ethic: A Moderator between Organizational Commitment and Job Satisfaction in a Cross-Cultural Context. Personnel Review, 30(2), 152-169.

49. Yousef, A. D. (2002). Job Satisfaction As A Mediator of the Relationship Between Role Stressors and Organizational Commitment: A Study From an Arabic Cultural Perspective. Journal of Managerial Psychology, 17(4), 250-266. 